\title{
Maximizing profit on New England organic dairy farms: An economic comparison of 4 total mixed rations for organic Holsteins and Jerseys ${ }^{1}$
}

\author{
S. P. Marston, ${ }^{\star 2}$ G. W. Clark, † G. W. Anderson, $†$ R. J. Kersbergen, $\dagger$ M. Lunak, ${ }^{\star}$ D. P. Marcinkowski, $\dagger$ \\ M. R. Murphy, $¥$ C. G. Schwab, ${ }^{\star}$ and P. S. Erickson ${ }^{* 3}$ \\ ${ }^{*}$ Department of Biological Sciences, University of New Hampshire, Durham 03824 \\ †Department of Animal and Veterinary Sciences, University of Maine, Orono 04469 \\ ‡Department of Animal Sciences, University of Illinois, Urbana 61801
}

\section{ABSTRACT}

The objective of these experiments was to compare 4 total mixed rations fed to USDA-certified organic dairy cows in New England. Forty-eight Jersey cows from the University of New Hampshire (UNH) and 64 Holstein cows from the University of Maine (UMaine) were assigned to a $2 \times 2$ factorial arrangement of treatments testing the main effects of corn silage versus grass silage as the forage base and commodity concentrates versus a complete pelleted concentrate mixture. Treatment diets were fed as a total mixed ration for 8 wk during the winter and spring months of 2007, 2008, and 2009. Milk yield, component, and quality data were recorded and used to calculate the value of the milk produced for each cow. The dry matter intake (DMI) was recorded and used to calculate the average cost per cow per day of each diet. Income over feed costs were calculated for each diet using milk value and feed cost data. Feed cost and income over feed cost data were resampled using bootstrap methodology to examine potential patterns. Milk yield, milk fat and true protein concentrations, and SCC were similar among treatments. Cows at UNH fed corn silage tended to have higher DMI and lower milk urea nitrogen than did cows fed grass silage, whereas cows fed pellets had higher DMI than cows fed commodities. Cows at UNH fed commodities tended to have higher body condition scores than those fed pellets. Cows at UMaine fed commodities tended to have higher DMI than did cows fed pellets, and cows fed corn silage had lower milk urea nitrogen than did cows fed grass silage. Body weights and body condition scores were not different for cows at UMaine. Feed costs were significantly higher for corn silage diets and diets at UNH containing pellets, but not at UMaine. The calculated value of the milk and income over feed costs

Received September 1, 2010.

Accepted December 1, 2010.

${ }^{1}$ This is Scientific Contribution number 2439 from the New Hampshire Agricultural Experiment Station.

${ }^{2}$ Current address: 307 Terrill Building Department of Animal Science, University of Vermont, Burlington 05405.

${ }^{3}$ Corresponding author: peter.erickson@unh.edu did not differ among treatments at either university. Bootstrap replications indicated that the corn silage with commodities diet generally had the highest feed cost at both UNH and UMaine, whereas grass silage diets containing commodities generally had the lowest cost. In contrast, the grass silage with commodities diets had the highest income over feed cost in the majority of the replications at both UNH and UMaine replications, whereas the corn silage with commodities diets had the lowest rank. Similar results were observed when forage prices were increased or decreased by 5,10 , and $25 \%$ above or below the actual feed price. Feeding a grass silage-based diet supplemented with commodity concentrates may have an economic advantage for dairy producers in New England operating under an organic system of production.

Key words: organic, income over feed costs (IOFC), economic, supplementation

\section{INTRODUCTION}

The organic dairy industry is one of the fastest growing segments of US organic agriculture. The number of certified organic dairy cows in the United States grew about $25 \%$ per year between 2000 and 2005, and estimates indicate that organic milk increased from $2 \%$ of US fluid milk product sales in 2006 to $3 \%$ in 2008 (McBride and Greene, 2009). At present, there are just over 1,600 certified organic dairy farms in the United States and the majority of these farms are located between the Northeast and Upper Midwest regions.

Transitioning to the production of USDA-certified organic milk has been beneficial for many dairies in the Northeast and parts of the Midwest because this management system requires the use of pasture during the grazing season and many of the small dairies in these regions practice rotational grazing. Rotational grazing has several potential advantages, including improved herd health, decreased capital investment requirements, and decreased time spent cropping (Gloy et al., 2002). However, climatic conditions of the Northeast and the Midwest require the harvest and storage of feeds for the winter months. 
Producing high-quality stored forages for use during the winter months may decrease the amount of expensive concentrates required to attempt to meet the nutrient requirements of lactating dairy cows. In the Northeast, corn silage has typically made up the bulk of rations fed to lactating dairy cows, as corn silage, which is an excellent source of fermentable carbohydrate, provides fiber to promote normal rumen function and is readily consumed by the animal and easily stored in silos (Johnson et al., 1999). However, during the transition process from conventional to organic production, many producers are forced to convert more acreage into perennial crop production to meet the grazing guidelines set forth by the National Organic Program (NOP). Therefore, the production of perennial silages is increasing in popularity among New England dairy producers using an organic system of production. When harvested at the correct stage of maturity, alfalfa/grass silages can contain similar protein concentrations to that of pasture. However, the $\mathrm{CP}$ contained in grass silage can be rapidly degraded in the rumen, which may cause an increase in rumen $\mathrm{NH}_{3}$ concentrations and often leads to excess $\mathrm{N}$ excretion into the environment.

Fermentable carbohydrates may improve the utilization of NPN in alfalfa/grass silages through stimulation of microbial protein synthesis. However, diets containing alfalfa/grass silages as the sole forage usually require additional supplementation of RUP (Broderick, 1995). The prices of certified organic feedstuffs are generally 2 to 3 times higher than prices of conventionally grown feeds; therefore, the additional cost of organic feeds needed to maintain production during the winter months results in lower profit margins. Dhiman and Satter (1997) reported greater DMI and milk yield in lactating cows fed diets in which the forage portion of the diet consisted of two-thirds alfalfa silage and one-third corn silage. However, with fewer acres available for corn silage production, dairy producers in the Northeast following an organic system of production are concerned with how best to feed their cows during the winter months.

Data that compare the feeding systems of organically managed dairy cows during the winter months, when pasture is not an option, are lacking. Therefore, the objective of these experiments was to compare the milk production, feed costs, and the income over feed costs (IOFC) of 4 TMR commonly fed on dairy farms in New England that follow NOP guidelines.

\section{MATERIALS AND METHODS}

\section{Overview of Experimental Approach}

All experiments involving the use of vertebrate animals were reviewed and approved by the University of
New Hampshire Institutional Animal Care and Use Committee as well as the University of Maine Institutional Animal Care and Use Committee.

Two experiments were simultaneously conducted at the Organic Dairy Research Farm, located at the University of New Hampshire (UNH; Durham, NH) and the J. F. Witter Center, located at the University of Maine (UMaine; Orono, ME). These experiments were part of a larger cohort study geared at decreasing the reliance of USDA-certified organic dairy farms in New England on grains imported from the Midwest and Canada. Specifically, the purpose of this project was to compare 2 cropping systems (corn silage or no corn silage) used to feed dairy cows in New England that are managed using an organic system of production during the winter confinement period, and to determine the amount and type of grain (purchased complete pellet versus home-grown grains) needed to successfully supplement each cropping system while improving profitability and whole-farm nutrient flows. The forage and concentrate systems, outlined in Table 1 , were developed with the assistance of organic dairy producers from within the Northeast region.

During the experimental periods, cows were randomly allocated into 4 treatment groups, with 6 cows per treatment at UNH and 8 cows per treatment at UMaine. Cows from both institutions were blocked according to expected calving date and randomized within block. Primiparous and multiparous cows were blocked separately to ensure an equal number of primiparous and multiparous cows on each treatment. The UMaine herd is not certified organic; however, during the experimental period experimental cows were fed and managed according to NOP guidelines.

\section{Experimental Design}

Experiments were conducted from March to May of 2008 and 2009 at UNH and from February to April of 2007 and 2008 at UMaine. During each experimental period, 24 organic Jersey cows [BW $405 \pm 10 \mathrm{~kg}$; milk yield $23.3 \pm 1.2 \mathrm{~kg} / \mathrm{d} ;$ DIM $42 \pm 11 \mathrm{~d}$ (mean $\pm \mathrm{SD}$ )] from UNH and 32 organically managed Holstein cows [BW $679 \pm 13 \mathrm{~kg}$; milk yield $30.3 \pm 3.9 \mathrm{~kg} / \mathrm{d}$; DIM $79 \pm 10 \mathrm{~d}$ (mean $\pm \mathrm{SD}$ )] from UMaine were assigned to a $2 \times 2$ factorial arrangement of treatments, testing the main effects of corn silage (CS) versus grass silage (GS) as the forage source, and individual concentrate commodities (C; UNH: corn meal, whole roasted soybeans; UMaine: corn meal, whole roasted soybeans, soybean meal, triticale grain) versus a commercially available pelleted grain $(\mathbf{P} ; 20 \%$ of CP, Blue Seal Feeds, Londonderry, $\mathrm{NH}$ ) as the concentrate supplement. Treatment groups were as follows: 1) corn silage as 
Table 1. Representative New England organic dairy forage and concentrate systems

\begin{tabular}{|c|c|c|c|c|c|c|c|c|c|c|c|c|}
\hline \multirow[b]{2}{*}{ System } & \multicolumn{3}{|c|}{ Year 1} & \multicolumn{3}{|c|}{ Year 2} & \multicolumn{3}{|c|}{ Year 3} & \multicolumn{3}{|c|}{ Year 4} \\
\hline & Spring & Summer & Fall & Spring & Summer & Fall & Spring & Summer & Fall & Spring & Summer & Fall \\
\hline \multicolumn{13}{|l|}{ Corn silage } \\
\hline $\mathrm{C}^{1}$ & $\begin{array}{l}\text { Till } \\
\text { perennial } \\
\text { sod }\end{array}$ & Corn silage & $\begin{array}{l}\text { Triticale for } \\
\text { early chop }\end{array}$ & $\begin{array}{l}\text { Triticale for } \\
\text { early chop }\end{array}$ & $\begin{array}{r}\text { Corn } \\
\text { grain }\end{array}$ & Corn grain & $\begin{array}{l}\text { Barley grain } \\
\text { under-sown } \\
\text { with alfalfa/ } \\
\text { ryegrass }\end{array}$ & $\begin{array}{l}\text { Barley grain } \\
\text { under-sown } \\
\text { with alfalfa/ } \\
\text { ryegrass }\end{array}$ & $\begin{array}{l}\text { Alfalfa/ } \\
\text { ryegrass }\end{array}$ & $\begin{array}{l}\text { Alfalfa/ } \\
\text { ryegrass }\end{array}$ & $\begin{array}{l}\text { Alfalfa/ } \\
\text { ryegrass }\end{array}$ & $\begin{array}{l}\text { Alfalfa/ } \\
\text { ryegrass }\end{array}$ \\
\hline $\mathrm{P}^{2}$ & $\begin{array}{l}\text { Till } \\
\text { perennial } \\
\text { sod }\end{array}$ & Corn silage & $\begin{array}{l}\text { Triticale for } \\
\text { early chop }\end{array}$ & $\begin{array}{l}\text { Triticale for } \\
\text { early chop }\end{array}$ & $\begin{array}{l}\text { Corn } \\
\text { silage }\end{array}$ & $\begin{array}{l}\text { Triticale for } \\
\text { early chop }\end{array}$ & $\begin{array}{l}\text { Triticale for } \\
\text { early chop }\end{array}$ & BMRSS & Fallow & $\begin{array}{l}\text { Alfalfa/ } \\
\text { ryegrass }\end{array}$ & $\begin{array}{l}\text { Alfalfa/ } \\
\text { ryegrass }\end{array}$ & $\begin{array}{l}\text { Alfalfa/ } \\
\text { ryegrass }\end{array}$ \\
\hline \multicolumn{13}{|c|}{ Grass/legume silage } \\
\hline $\mathrm{C}^{1}$ & $\begin{array}{l}\text { Till } \\
\text { perennial } \\
\text { sod }\end{array}$ & BMRSS $^{3}$ & $\begin{array}{l}\text { Triticale } \\
\text { grain }\end{array}$ & $\begin{array}{l}\text { Triticale } \\
\text { grain }\end{array}$ & $\begin{array}{l}\text { Triticale } \\
\text { grain }\end{array}$ & Fallow & $\begin{array}{l}\text { Barley grain } \\
\text { under-sown } \\
\text { with alfalfa/ } \\
\text { ryegrass }\end{array}$ & $\begin{array}{l}\text { Barley grain } \\
\text { under-sown } \\
\text { with alfalfa/ } \\
\text { ryegrass }\end{array}$ & $\begin{array}{l}\text { Alfalfa/ } \\
\text { ryegrass }\end{array}$ & $\begin{array}{l}\text { Alfalfa/ } \\
\text { ryegrass }\end{array}$ & $\begin{array}{l}\text { Alfalfa/ } \\
\text { ryegrass }\end{array}$ & $\begin{array}{l}\text { Alfalfa/ } \\
\text { ryegrass }\end{array}$ \\
\hline \multicolumn{13}{|c|}{ Hegtass tyegrosis } \\
\hline Option 1 & $\begin{array}{l}\text { Till } \\
\text { perennial } \\
\text { sod }\end{array}$ & BMRSS & $\begin{array}{l}\text { Triticale for } \\
\text { early chop }\end{array}$ & $\begin{array}{l}\text { Triticale for } \\
\text { early chop }\end{array}$ & r BMRSS & $\begin{array}{l}\text { Triticale for } \\
\text { soft dough } \\
\text { silage } \\
\text { harvest }\end{array}$ & $\begin{array}{l}\text { Triticale for } \\
\text { soft dough } \\
\text { silage } \\
\text { harvest }\end{array}$ & $\begin{array}{l}\text { Triticale for } \\
\text { soft dough } \\
\text { silage harvest }\end{array}$ & $\begin{array}{l}\text { Alfalfa/ } \\
\text { ryegrass }\end{array}$ & $\begin{array}{l}\text { Alfalfa/ } \\
\text { ryegrass }\end{array}$ & $\begin{array}{l}\text { Alfalfa/ } \\
\text { ryegrass }\end{array}$ & $\begin{array}{l}\text { Alfalfa/ } \\
\text { ryegrass }\end{array}$ \\
\hline Option 2 & $\begin{array}{l}\text { Till } \\
\text { perennial } \\
\text { sod }\end{array}$ & $\begin{array}{l}\text { Alfalfa/ } \\
\text { ryegrass }\end{array}$ & $\begin{array}{l}\text { Alfalfa/ } \\
\text { ryegrass }\end{array}$ & $\begin{array}{l}\text { Alfalfa/ } \\
\text { ryegrass }\end{array}$ & $\begin{array}{l}\text { Alfalfa/ } \\
\text { ryegrass }\end{array}$ & $\begin{array}{l}\text { Alfalfa/ } \\
\text { ryegrass }\end{array}$ & $\begin{array}{l}\text { Alfalfa/ } \\
\text { ryegrass }\end{array}$ & $\begin{array}{l}\text { Alfalfa/ } \\
\text { ryegrass }\end{array}$ & $\begin{array}{l}\text { Alfalfa/ } \\
\text { ryegrass }\end{array}$ & $\begin{array}{l}\text { Alfalfa/ } \\
\text { ryegrass }\end{array}$ & $\begin{array}{l}\text { Alfalfa/ } \\
\text { ryegrass }\end{array}$ & $\begin{array}{l}\text { Alfalfa/ } \\
\text { ryegrass }\end{array}$ \\
\hline Option 3 & $\begin{array}{l}\text { Leave } \\
\text { perennial } \\
\text { sod }\end{array}$ & $\begin{array}{l}\text { Existing } \\
\text { sod }\end{array}$ & $\begin{array}{l}\text { Existing } \\
\text { sod }\end{array}$ & $\begin{array}{l}\text { Existing } \\
\text { sod }\end{array}$ & $\begin{array}{l}\text { Existing } \\
\text { sod }\end{array}$ & $\begin{array}{l}\text { Existing } \\
\text { sod }\end{array}$ & $\begin{array}{l}\text { Existing } \\
\text { sod }\end{array}$ & $\begin{array}{l}\text { Existing } \\
\text { sod }\end{array}$ & $\begin{array}{l}\text { Existing } \\
\text { sod }\end{array}$ & $\begin{array}{l}\text { Existing } \\
\text { sod }\end{array}$ & $\begin{array}{l}\text { Existing } \\
\text { sod }\end{array}$ & $\begin{array}{l}\text { Existing } \\
\text { sod }\end{array}$ \\
\hline
\end{tabular}

${ }^{2} \mathrm{P}=$ purchased complete pelleted grain mixture used to balance rations fed during the winter confinement period.

${ }^{3}$ BMRSS $=$ brown mid-rib Sorghum Sudan silages. 
Table 2. Ingredient composition of experimental diets fed to University of New Hampshire (UNH) cows $^{1}$

\begin{tabular}{|c|c|c|c|c|c|c|c|c|}
\hline Composition $^{2}$ (\% of DM) & \multicolumn{4}{|c|}{ Treatment diet 2008} & \multicolumn{4}{|c|}{ Treatment diet 2009} \\
\hline Corn silage & 46.89 & 41.60 & & & 20.44 & 20.02 & & \\
\hline Alfalfa hay & 11.99 & 12.27 & 15.40 & 15.48 & 17.36 & 17.00 & 6.52 & 6.58 \\
\hline Corn, dry ground & 8.79 & & 14.23 & & 24.97 & & 17.68 & \\
\hline Soybeans, whole heated & 6.52 & & 5.87 & & 10.34 & & 8.70 & \\
\hline
\end{tabular}

${ }^{1} \mathrm{CSC}=$ corn silage-based diet supplemented with commodity concentrates; CSP = corn silage-based diet supplemented with a pelleted concentrate mixture; GSC = grass silage-based diet supplemented with commodity concentrates; GSP = grass silage-based diet supplemented with a pelleted concentrate mixture.

${ }^{2}$ Composition of diets are means over the 8 -wk period from weekly sampling.

${ }^{3}$ Concentrate pellets were custom formulated to mimic the CP level of commodity concentrate supplements.

${ }^{4}$ Diets were formulated to meet NRC (2001) requirements for minerals and vitamins.

the primary forage source with commodity concentrate supplementation (treatment CSC); 2) corn silage as the primary forage source with a commercial pelleted concentrate supplement (treatment CSP); 3) grass silage as the primary forage source with commodity concentrate supplementation (treatment GSC); and 4) grass silage as the primary forage source with a pelleted concentrate supplement (treatment GSP). The ingredient composition of the experimental diets from UNH and UMaine are presented in Table 2 and Table 3 , respectively. Experimental diets were formulated to contain no more than $40 \%$ of concentrates and were balanced for similar levels of milk production attainable under this constraint, using NRC (2001) and CPM-Dairy (version 2.0) ration balancing software.

Experimental periods for UNH consisted of $60 \mathrm{~d}$, with a 1-wk covariate collection period before the start of the experiment, whereas the experimental period for cows at UMaine consisted of $90 \mathrm{~d}$, with a 1-wk pretreatment covariate period. Cows remained on their assigned treatment for the duration of the experimental period, and were randomly assigned to different treatments in each of the $3 \mathrm{yr}$.

Cows at UNH were housed in a bedded-pack barn and fed a TMR using a Knight feed mixer (Reel Augie model 3250, Broadhead, WI). Cows were grouped and fed as a pen 1 time per day in open mangers at $1400 \mathrm{~h}$. Prior to feeding, the previous day's feed refusals were removed and weighed to estimate pen DMI. Cows were milked twice daily at 12-h intervals (0400 and $1600 \mathrm{~h})$ in a 4-stall walk-through parlor. University of Maine cows were housed in a tie-stall barn and were group-fed a TMR using a Knight feed mixer (Reel Augie model 3020). Cows were fed the TMR once daily at $0800 \mathrm{~h}$.

Table 3. Ingredient composition of experimental diets fed to University of Maine (UMaine) cows ${ }^{1}$

\begin{tabular}{|c|c|c|c|c|c|c|c|c|}
\hline \multirow[b]{2}{*}{ Composition $^{2}(\%$ of DM) } & \multicolumn{4}{|c|}{ Treatment diet 2007} & \multicolumn{4}{|c|}{ Treatment diet 2008} \\
\hline & $\mathrm{CSC}$ & CSP & GSC & GSP & $\mathrm{CSC}$ & $\mathrm{CSP}$ & GSC & GSP \\
\hline Grass silage, first cut & 7.39 & 7.50 & 20.01 & 18.72 & 6.56 & 4.83 & 17.14 & 15.16 \\
\hline Grass silage, second cut & 7.30 & 7.40 & 19.72 & 18.45 & 10.97 & 8.11 & 28.77 & 25.33 \\
\hline Grass silage, third cut & 9.55 & 9.69 & 25.85 & 24.19 & 8.44 & 6.19 & 22.04 & 19.49 \\
\hline Triticale silage & 11.57 & 11.76 & & & 5.86 & 5.82 & & \\
\hline Soybeans, whole heated & 12.32 & & 12.70 & & 10.42 & & 11.65 & \\
\hline Soybean meal $(48 \%)$ & 6.52 & & 3.10 & & 3.47 & & & \\
\hline Triticale grain, dry ground & & & & & 3.47 & & 3.48 & \\
\hline Concentrate pelleted mixture $(20 \% \text { of } \mathrm{CP})^{3}$ & & 33.21 & & 38.64 & & 39.99 & & 40.02 \\
\hline Minerals and vitamins ${ }^{4}$ & 0.57 & & 0.54 & & 0.29 & & 0.22 & \\
\hline
\end{tabular}

${ }^{1} \mathrm{CSC}=$ corn silage-based diet supplemented with commodity concentrates; CSP = corn silage-based diet supplemented with a pelleted concentrate mixture; GSC = grass silage-based diet supplemented with commodity concentrates; GSP = grass silage-based diet supplemented with a pelleted concentrate mixture.

${ }^{2}$ Composition of diets are means over the 8 -wk period from weekly sampling.

${ }^{3}$ Concentrate pellets were custom formulated to mimic the CP level of commodity concentrate supplements.

${ }^{4}$ Diets were formulated to meet NRC (2001) requirements for minerals and vitamins. 
Prior to feeding, the previous day's feed refusals were removed and weighed to estimate the DMI of the group. Cows were milked in their respective stalls twice daily at 12-h intervals (0400 and $1600 \mathrm{~h}$ ), using a pipeline milking system.

\section{Sampling and Measurements}

The milk yield from cows at both locations was recorded daily. Milk samples were taken weekly from each cow during consecutive morning and evening milkings. Milk samples were composited based on production during the morning and evening milking and were sent to Dairy One (Ithaca, NY) for analysis. Samples were analyzed for fat, true protein, MUN, and SCC. Milk quality and yield data were used to calculate the dollar value of the milk from each cow based on current New England prices for organic milk (CROPP Co-operative, LaFarge, WI). Because cows were housed and fed as a group and not individually, each group was considered an experimental unit. Therefore, all individual observations of milk yield, milk components, and milk value were averaged to obtain a daily measurement from each experimental group and daily observations were averaged for each week of the study.

Body condition scores were taken every 2 wk at each university by 3 independent scorers, blind to the treatments. Body weights were determined monthly at UNH and UMaine using a Gallagher Smart Scale (model 500, Gallagher USA, Kansas City, MO) and an RWLS IQ Plus scale (model 390-DC, Rice Lake Weighing Systems, Rice Lake, WI), respectively. All individual cow measurements were used to calculate the group mean.

\section{Feed Sampling and Analysis}

All feeds used during the course of the feeding experiments were sampled weekly and tested for quality, using wet chemistry. Samples were sent (as is) to Dairy One Forage Laboratory (Ithaca, NY) and were analyzed for DM, CP, NDF, ADF, neutral detergent insoluble protein (NDIP), fat, ash, NFC, $\mathrm{pH}$, and mineral concentrations, according to AOAC International (2002) methods.

\section{Economic Calculations}

The average cost of each experimental diet was calculated daily and then averaged for each week. The cost of the ration was calculated as the amount fed to the pen (as-fed basis) divided by the number of cows per pen. The cost of all feed ingredients used throughout these experiments is in Table 4 . The value of the milk produced was calculated based on milk yield, compo- nent yield, and quality, using New England organic milk prices. In addition, IOFC was calculated by subtracting the average cost of the ration from value of the milk produced for each experimental group.

\section{Statistical Methods}

Dry matter intake, milk yield, milk composition, BW, BCS, milk value, feed cost, and IOFC data from each university were analyzed using the MIXED procedure of SAS (Version 9.2; SAS Institute, Inc., Cary, NC). Data were analyzed as a completely random design, according to the following model:

$$
Y_{i j k l}=\mu+S_{i}+C_{j}+W_{k}+S C_{i j}+P_{l: i}+e_{i j k l},
$$

where $Y_{i j k l}$ are the observed values, $\mu$ is the overall population mean, $S_{i}$ is the fixed effect of the $i$ th silage treatment ( $i=\mathrm{CS}$ or GS), $C_{j}$ is the fixed effect of the $j$ th concentrate supplement $(j=\mathrm{C}$ or $\mathrm{P}), W_{k}$ is the fixed effect of the $k$ th week on study, $S C_{i j}$ is the fixed effect of the interaction between the $i$ th silage treatment and the $j$ th concentrate supplement, $P_{l: i}$ is the random effect of the lth cow nested within the $i$ th pen, and $e_{i j k l}$ is the residual error.

The model statement used to conduct the ANOVA included the fixed effects of treatments (type of silage and concentrate), week, and the interaction between the type of silage and type of concentrate, the random effect cow nested within pen, and the residual error. Residual errors were modeled using the autoregressive (1) covariance structure. Satterthwaite-based degrees of freedom were calculated using the Kenward-Roger option of the PROC MIXED (SAS Institute, 2004). Significance was declared at $P \leq 0.05$ and a trend in the data was declared at $P \leq 0.10$. Covariate adjustment measurements were not significant $(P>0.10)$ and were removed from the final model.

The univariate procedure of SAS was used to determine outlier samples. Observations greater than 2.5 standard deviations from the mean for each item analyzed were considered outliers and were removed from the final statistical analysis.

Bootstrap methodology (Efron, 1982; Boos, 2003; Janovick-Guretzky et al., 2007) was used to resample feed cost and IOFC data from both universities, to determine if one of the experimental diets could be consistently ranked above the others. The bootstrap method of re-sampling is a computer-intensive procedure that creates a simulated population and calculates an empirical distribution for a sample statistic through repeated sampling with replacement from the original data set (Chernick, 1999). Data were bootstrapped by using the MULTTEST procedure of SAS (Version 9.2; 
Table 4. Price list (\$) for feedstuffs fed to University of New Hampshire (UNH) and University of Maine (UMaine) cows $^{1}$

\begin{tabular}{|c|c|c|c|}
\hline Item & 2007 & 2008 & 2009 \\
\hline \multicolumn{4}{|l|}{ UNH ingredient } \\
\hline Corn silage & & 45.00 & 45.00 \\
\hline Grass silage & & 55.00 & 55.00 \\
\hline Alfalfa hay & & 280.00 & 275.00 \\
\hline Corn, dry ground & & 574.00 & 574.00 \\
\hline Soybeans, whole heated & & 814.00 & 890.00 \\
\hline Concentrate pelleted mixture ( $20 \%$ of $\mathrm{CP}$ ) & & 513.00 & 628.00 \\
\hline Minerals and vitamins & & 190.00 & 190.00 \\
\hline \multicolumn{4}{|l|}{ UMaine } \\
\hline Corn silage & 45.00 & 45.00 & \\
\hline Grass silage, first cut & 55.00 & 55.00 & \\
\hline Grass silage, second cut & 55.00 & 55.00 & \\
\hline Grass silage, third cut & 55.00 & 55.00 & \\
\hline Triticale silage & 45.00 & & \\
\hline Sorghum silage & & 45.00 & \\
\hline Corn, dry ground & 382.00 & 574.00 & \\
\hline Soybeans, whole heated & 800.00 & 814.00 & \\
\hline Soybean meal $(48 \%)$ & 720.00 & 720.00 & \\
\hline Triticale grain, dry ground & & 400.00 & \\
\hline Concentrate pelleted mixture ( $20 \%$ of $\mathrm{CP})$ & 432.00 & 513.00 & \\
\hline Minerals and vitamins & 180.00 & 190.00 & \\
\hline
\end{tabular}

${ }^{1}$ Prices listed are on a 907-kg, as-fed basis.

SAS Institute, Inc.), in which values from the original data set were averaged to create the bootstrap samples, according to the following model:

$$
\bar{Y}_{b}^{*}=\frac{\sum_{i=1}^{n} Y_{b i}^{*}}{n},
$$

where $\bar{Y}_{b}^{*}$ is the mean of the calculated bootstrap samples, $Y_{b i}^{*}$ are the bootstrap samples, $\sum_{i=1}^{n}$ is the sum of the ith subsamples for each observation, and $n$ is the number of samples used to average the subsamples.

Using the bootstrap methodology, the original feed cost and IOFC observations were resampled to make new feed cost and IOFC data sets with 1,000 new observations for each of the experimental diets. Each of these new data sets was then imported into Microsoft Excel and the rank order was calculated for each set of new values. Feed cost data were ranked 1 through 4, with 1 indicating the lowest and most desirable value and 4 indicating the highest and least desirable value. Income over feed cost data were also ranked 1 through 4, with 1 indicating the lowest income and least profitable and 4 indicating the highest income and, therefore, most desirable. One thousand bootstrap samples were selected because 1,000 simulated sets are desirable for a 95\% confidence interval in biological measures (Manly, 1997).

Sensitivity analysis was conducted for feed cost and IOFC data, by increasing or decreasing the forage prices by 5,10 , or $25 \%$ above or below the actual price and by increasing or decreasing the grain prices by the same margins. Feed cost and the resulting IOFC data were then bootstrapped as described previously to determine the effect of price changes on the potential profitability of each experimental diet.

\section{RESULTS AND DISCUSSION}

\section{Feed Analysis}

The nutrient analyses of feedstuffs fed to UNH cows during the 2 experimental periods $(2008,2009)$ are presented in Table 5. The CP concentration of the diets was similar during the $2 \mathrm{yr}$ of the experiment. Diets fed during 2008 had greater forage-to-concentrate ratios than in 2009. The CP concentrations of grass silagebased diets were greater than those of corn silage-based diets in both 2008 and 2009. Dietary percentages (DM basis) of NDF and ADF were slightly higher in 2008 than 2009, reflecting the greater proportion of forage in those diets. The 2007 growing season had higher average temperatures and lower overall precipitation, allowing for more timely harvest of grasses used to make grass silages. The 2008 growing season had higher than average precipitation for the Northeast region, resulting in grasses being harvested at a greater maturity than in the previous year.

The nutrient composition of UMaine feedstuffs is shown in Table 6. Forage-to-concentrate ratios for UMaine diets were similar during both years of the experiment. However, forages fed during the 2008 
MARSTON ET AL.

Table 5. Nutrient composition of experimental diets fed to University of New Hampshire (UNH) cows $^{1}$

\begin{tabular}{|c|c|c|c|c|c|c|c|c|}
\hline \multirow{2}{*}{$\begin{array}{l}\text { Nutrient } \\
\text { composition }^{2} \\
(\% \text { of DM })\end{array}$} & \multicolumn{4}{|c|}{ Treatment diet 2008} & \multicolumn{4}{|c|}{ Treatment diet 2009} \\
\hline & $\mathrm{CSC}$ & CSP & GSC & GSP & $\mathrm{CSC}$ & CSP & GSC & GSP \\
\hline $\mathrm{CP}$ & 14.9 & 15.1 & 16.9 & 17.8 & 14.7 & 15.4 & 18.4 & 18.7 \\
\hline $\mathrm{RDP}$ & 10.2 & 10.0 & 12.2 & 12.0 & 10.3 & 10.4 & 13.3 & 13.2 \\
\hline RUP & 4.6 & 5.1 & 4.8 & 5.8 & 4.3 & 5.0 & 5.1 & 5.5 \\
\hline $\mathrm{NDF}$ & 38.2 & 39.3 & 39.6 & 36.9 & 37.9 & 36.4 & 34.5 & 33.9 \\
\hline $\mathrm{ADF}$ & 25.7 & 23.9 & 23.9 & 22.4 & 22.8 & 22.2 & 20.9 & 20.8 \\
\hline $\mathrm{NFC}$ & 34.8 & 36.1 & 37.4 & 36.6 & 37.8 & 36.3 & 36.9 & 35.4 \\
\hline Ether extract & 4.8 & 2.9 & 4.5 & 3.0 & 4.8 & 2.9 & 5.2 & 3.0 \\
\hline
\end{tabular}

${ }^{1} \mathrm{CSC}=$ corn silage-based diet supplemented with commodity concentrates; $\mathrm{CSP}=$ corn silage-based diet supplemented with a pelleted concentrate mixture; GSC = grass silage-based diet supplemented with commodity concentrates; GSP = grass silage-based diet supplemented with a pelleted concentrate mixture.

${ }^{2}$ Composition of diets are means over the 8 -wk period from weekly sampling.

experiment had higher $\mathrm{CP}$ and lower NDF and ADF concentrations than in 2007, resulting in higher CP and lower NDF and ADF concentrations of the rations fed in 2008 compared with those fed in 2007. Brown mid-rib Sorghum Sudan silages (BMRSS) and boot stage triticale silages were not included in the UMaine rations in 2007 due to crop failures; however, both BMRSS and soft dough oat silage were included in the 2008 experimental rations. Similar to UNH, forages fed during the 2008 experiment were the highest quality. Overall, the 2006 growing season had average rainfall; however, higher than normal temperatures in August of 2006 resulted in drought-like conditions, which negatively affected the quality of the third-cut grass silage.

\section{Milk Yield and Composition}

Average DMI, milk yield, and milk composition data from UNH are presented in Table 7. No differences were found among treatments for milk yield, milk fat, or true protein concentrations, or SCC for UNH cows. University of New Hampshire cows fed CS tended to have higher DMI than did cows fed GS. No interactions between forage type or concentrate source existed. Cows fed CS tended to have lower MUN concentrations than did cows fed GS as the forage base, but the interactions were not different (Table 7 ).

Table 8 shows the DMI, milk yield, and milk composition data for UMaine. The milk yield, concentrations of milk fat and true protein, and SCC for cows at UMaine were similar. However, UMaine cows fed C tended to have higher DMI than cows fed P. Cows fed CS had lower $(P<0.01)$ MUN concentrations than did cows fed GS, similar to UNH cows.

The DMI may have been higher in CS diets for UNH cows because of the smaller particle size of this diet. The dietary NDF concentrations of UNH rations were higher in CS diets than GS diets. The Penn State Particle Separator (Kononoff et al., 2003) indicated that CS diets had less effective fiber, and, therefore, less bulk. On average, CS diets had $6 \%$ remaining on the top screen compared with $10.5 \%$ for grass silage diets. Of interest, the diets used in the current study all had NDF concentrations above $30 \%$ (Table 5 and Table $6)$. Rations for lactating dairy cows should contain at least $25 \% \mathrm{NDF}$, with the majority of that coming from forages (Oba and Allen, 1999). VandeHaar and StPierre (2006) proposed that the optimal level of NDF

Table 6. Nutrient composition of experimental diets fed to University of Maine (UMaine) cows ${ }^{1}$

\begin{tabular}{|c|c|c|c|c|c|c|c|c|}
\hline \multirow{2}{*}{$\begin{array}{l}\text { Nutrient } \\
\text { composition }^{2} \\
(\% \text { of DM) }\end{array}$} & \multicolumn{4}{|c|}{ Treatment diet 2007} & \multicolumn{4}{|c|}{ Treatment diet 2008} \\
\hline & $\mathrm{CSC}$ & CSP & GSC & GSP & $\mathrm{CSC}$ & CSP & GSC & GSP \\
\hline $\mathrm{CP}$ & 16.2 & 14.3 & 18.1 & 16.7 & 17.1 & 17.2 & 20.3 & 21.3 \\
\hline RDP & 10.2 & 9.9 & 11.0 & 11.2 & 11.1 & 11.8 & 13.8 & 15.1 \\
\hline RUP & 6.0 & 4.4 & 7.2 & 5.5 & 6.0 & 5.4 & 6.5 & 6.2 \\
\hline NDF & 39.7 & 37.6 & 42.4 & 41.4 & 35.7 & 35.6 & 33.8 & 33.9 \\
\hline $\mathrm{ADF}$ & 24.7 & 24.1 & 27.3 & 27.6 & 22.1 & 22.6 & 22.9 & 23.7 \\
\hline NFC & 31.7 & 34.9 & 28.7 & 30.9 & 35.0 & 37.3 & 33.7 & 34.0 \\
\hline Ether extract & 4.1 & 3.7 & 4.9 & 4.7 & 4.6 & 4.5 & 5.1 & 4.6 \\
\hline
\end{tabular}

${ }^{1} \mathrm{CSC}=$ corn silage-based diet supplemented with commodity concentrates; $\mathrm{CSP}=$ corn silage-based diet supplemented with a pelleted concentrate mixture; GSC = grass silage-based diet supplemented with commodity concentrates; GSP = grass silage-based diet supplemented with a pelleted concentrate mixture.

${ }^{2}$ Composition of diets are means over the 8 -wk period from weekly sampling. 
Table 7. Average DMI, milk yield, milk composition, BW, and BCS of University of New Hampshire (UNH) cows fed either corn silage or grass silage supplemented with either commodity concentrates or a pelleted concentrate mixture over the 2 experimental periods

\begin{tabular}{|c|c|c|c|c|c|c|c|c|}
\hline \multirow[b]{2}{*}{ Item } & \multicolumn{4}{|c|}{ Treatment $^{1}$} & \multirow[b]{2}{*}{ SEM } & \multicolumn{3}{|c|}{ Significance ( $P$-value) } \\
\hline & CSC & $\mathrm{CSP}$ & GSC & GSP & & Forage $(\mathrm{F})$ & Concentrate $(\mathrm{C})$ & $\mathrm{F} \times \mathrm{C}$ \\
\hline Milk (kg/d) & 23.2 & 22.9 & 24.5 & 22.6 & 1.1 & 0.64 & 0.35 & 0.44 \\
\hline Fat $(\%)$ & 4.3 & 4.5 & 4.6 & 4.3 & 0.1 & 0.57 & 0.69 & 0.60 \\
\hline True protein $(\%)$ & 3.3 & 3.3 & 3.3 & 3.4 & 0.07 & 0.37 & 0.25 & 0.65 \\
\hline $\operatorname{MUN}^{1}(\mathrm{mg} / \mathrm{dL})$ & 10.8 & 12.9 & 17.13 & 14.3 & 2.0 & 0.07 & 0.85 & 0.24 \\
\hline $\mathrm{BCS}$ & 2.7 & 2.7 & 2.8 & 2.6 & 2.7 & 0.97 & 0.10 & 0.97 \\
\hline
\end{tabular}

${ }^{1} \mathrm{CSC}=$ corn silage-based diet supplemented with commodity concentrates; CSP = corn silage-based diet supplemented with a pelleted concentrate mixture; GSC = grass silage-based diet supplemented with commodity concentrates; GSP = grass silage-based diet supplemented with a pelleted concentrate mixture.

is between 25 and $30 \%$, above which may inhibit feed energy intake. Consequently, DMI and energy intake were likely limited in this study due to the high forage content of the rations fed. The lack of difference in DMI from UMaine cows may have resulted from the inclusion of longer-cut cereal grain and sorghum silages in the corn silage-based diets at UMaine. The opposite effects of concentrate supplementation on DMI observed in this study are interesting and may have been merely caused by chance, as DMI was based on measurements of pen intake and not individual cows.

Cows at UNH fed GS tended to have higher MUN, whereas cows at UMaine fed GS had significantly higher MUN than did cows fed CS. These results were expected due to the high rumen degradability of protein in the grass silages fed during this study. When fermentable carbohydrates are fed with RDP, rumen ammonia concentrations are often decreased because of improved $\mathrm{N}$ uptake by rumen microorganism. The higher MUN concentrations in the GS diets at both UNH and UMaine suggest inefficient utilization of dietary protein, possibly due to an inadequate balance between RDP and NFC. In all diets, except for the
2008 UNH diet, NFC concentrations were higher for CS diets than for GS diets (Table 5 and Table 6). A well-balanced ration results in MUN in the range of 10 to $16 \mathrm{mg} / \mathrm{dL}$ (Jonker et al., 1998). Milk urea N concentrations from cows fed grass silage diets in this study were above $15 \mathrm{mg} / \mathrm{dL}$ and were numerically highest in GSC diets. Elevated MUN are often the result of excess dietary protein, which often occurs when feeding immature grasses and legumes or when supplemental protein is fed in excess. According to VandeHaar and St-Pierre (2006), efficiency of protein utilization for a herd averaging $35 \mathrm{~kg}$ of milk/d is maximized at a dietary CP of $14.9 \%$. University of New Hampshire corn silage diets were slightly higher than recommended CP values (Table 5), whereas grass silage diets were upwards of $19 \%$ of CP, indicating that protein may have been severely overfed and that excess nitrogen was most likely excreted into the environment; however, urinary $\mathrm{N}$ concentrations were not evaluated in this study.

\section{$B W$ and BCS}

The average BW of UNH and UMaine cows did not differ among treatments, nor did the average BCS of

Table 8. DMI, milk yield, milk composition, BW, and BCS of University of Maine (UMaine) cows fed either corn silage or grass silage supplemented with either commodity concentrates or a pelleted concentrate mixture over the 2 experimental periods

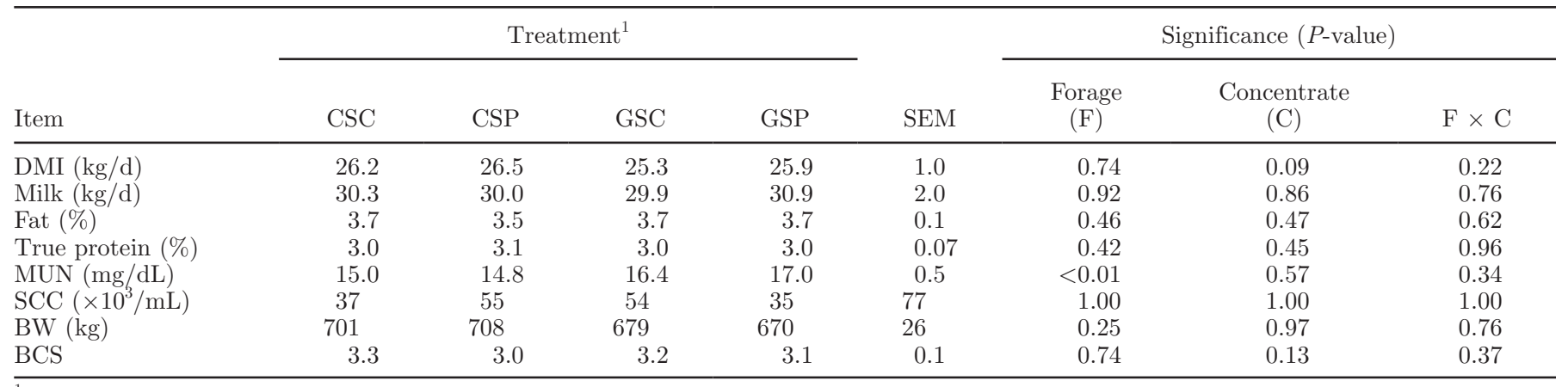

${ }^{1} \mathrm{CSC}=$ corn silage-based diet supplemented with commodity concentrates; CSP $=$ corn silage-based diet supplemented with a pelleted concentrate mixture; GSC = grass silage-based diet supplemented with commodity concentrates; GSP = grass silage-based diet supplemented with a pelleted concentrate mixture. 
Table 9. Economic data from University of New Hampshire (UNH) and University of Maine (UMaine) cows fed either corn silage or grass silage supplemented with either commodity concentrates or a pelleted concentrate mixture over the 2 experimental periods

\begin{tabular}{|c|c|c|c|c|c|c|c|c|}
\hline \multirow[b]{2}{*}{ Item } & \multicolumn{4}{|c|}{ Treatment $^{1}$} & \multirow[b]{2}{*}{ SEM } & \multicolumn{3}{|c|}{ Significance ( $P$-value) } \\
\hline & CSC & CSP & GSC & GSP & & $\begin{array}{l}\text { Forage } \\
\text { (F) }\end{array}$ & $\begin{array}{c}\text { Concentrate } \\
\text { (C) }\end{array}$ & $\mathrm{F} \times \mathrm{C}$ \\
\hline \multicolumn{9}{|l|}{ UNH } \\
\hline Milk value ( $\$ /$ cow per $d)$ & 15.49 & 15.42 & 15.19 & 15.08 & 0.82 & 0.41 & 0.19 & 0.22 \\
\hline Feed $(\$ /$ cow per $d)$ & 9.11 & 8.66 & 8.38 & 8.42 & 0.15 & 0.002 & 0.17 & 0.11 \\
\hline $\operatorname{IOFC}^{2}(\$ /$ cow per $\mathrm{d})$ & 6.38 & 6.76 & 6.81 & 6.66 & 0.72 & 0.51 & 0.90 & 0.34 \\
\hline \multicolumn{9}{|l|}{ UMaine } \\
\hline Feed $(\$ /$ cow per $d)$ & 8.11 & 7.83 & 7.57 & 7.81 & 0.14 & 0.45 & 0.91 & 0.66 \\
\hline $\operatorname{IOFC}(\$ /$ cow per $\mathrm{d})$ & 11.12 & 11.21 & 11.71 & 11.51 & 0.91 & 0.62 & 0.95 & 0.88 \\
\hline
\end{tabular}

${ }^{1} \mathrm{CSC}=$ corn silage-based diet supplemented with commodity concentrates; CSP = corn silage-based diet supplemented with a pelleted concentrate mixture; GSC = grass silage-based diet supplemented with commodity concentrates; GSP = grass silage-based diet supplemented with a pelleted concentrate mixture.

${ }^{2} \mathrm{IOFC}=$ income over feed costs.

UMaine cows. University of New Hampshire cows fed $\mathrm{C}$ tended $(P<0.1)$ to have higher BCS than those fed $\mathrm{P}$; however, the forage and concentrate interactions were not different (Table 7). The trend for higher BCS among UNH cows fed $\mathrm{C}$ may be explained by a combination of stage of lactation and the length of the study. Because semi-seasonal calving of the UNH herd occurred at the time of this study, only early lactation animals were used. Cows were blocked by calving date to ensure equal DIM across treatments; however, due to

Table 10. Descriptive statistics for the average rank of feed costs and income over feed costs (IOFC) following 1,000 bootstrap replications, with 1 indicating the lowest value and 4 indicating the highest value ${ }^{1}$

\begin{tabular}{|c|c|c|c|c|}
\hline Item $^{2}$ & $\begin{array}{l}\text { Lowest } \\
\operatorname{rank}^{3}(\%)\end{array}$ & $\begin{array}{l}\text { Highest } \\
\operatorname{rank}^{4}(\%)\end{array}$ & $\begin{array}{c}\text { Average } \\
\text { rank }\end{array}$ & $\mathrm{SE}$ \\
\hline \multicolumn{5}{|c|}{$\operatorname{Feed}^{5}(\$ /$ cow per d $)$} \\
\hline \multicolumn{5}{|c|}{ UNH } \\
\hline $\mathrm{CSC}$ & 20.3 & 51.1 & 2.94 & 0.04 \\
\hline CSP & 29.8 & 24.1 & 2.46 & 0.04 \\
\hline GSC & 36.4 & 7.9 & 2.03 & 0.03 \\
\hline GSP & 13.5 & 16.9 & 2.57 & 0.03 \\
\hline \multicolumn{5}{|c|}{ UMaine } \\
\hline $\mathrm{CSC}$ & 5.6 & 54.1 & 3.23 & 0.03 \\
\hline CSP & 25.2 & 24.5 & 2.44 & 0.04 \\
\hline GSC & 59.8 & 6.5 & 1.72 & 0.03 \\
\hline GSP & 9.4 & 14.9 & 2.60 & 0.03 \\
\hline \multicolumn{5}{|c|}{$\operatorname{IOFC}^{6}(\$ /$ cow per d) } \\
\hline \multicolumn{5}{|c|}{ UNH } \\
\hline $\mathrm{CSC}$ & 37.4 & 13.6 & 2.10 & 0.03 \\
\hline CSP & 28.6 & 20.3 & 2.36 & 0.03 \\
\hline GSC & 6.0 & 40.2 & 3.10 & 0.03 \\
\hline GSP & 28.0 & 25.9 & 2.45 & 0.04 \\
\hline \multicolumn{5}{|c|}{ UMaine } \\
\hline $\mathrm{CSC}$ & 40.1 & 16.0 & 2.12 & 0.04 \\
\hline CSP & 20.4 & 19.9 & 2.47 & 0.03 \\
\hline GSC & 17.1 & 38.4 & 2.83 & 0.04 \\
\hline GSP & 22.4 & 25.7 & 2.58 & 0.03 \\
\hline
\end{tabular}

${ }^{1}$ Feed cost and IOFC data are averages over the 2 experimental periods.

${ }^{2} \mathrm{UNH}=$ University of New Hampshire; UMaine = University of Maine; CSC $=$ corn silage-based diet supplemented with commodity concentrates; $\mathrm{CSP}=$ corn silage-based diet supplemented with a pelleted concentrate mixture; GSC = grass silage-based diet supplemented with commodity concentrates; GSP = grass silage-based diet supplemented with a pelleted concentrate mixture.

${ }^{3}$ Percent of 1,000 replications that each diet ranked lowest (rank of 1 ).

${ }^{4}$ Percent of 1,000 replications that each diet ranked highest (rank of 4).

${ }^{5}$ Lowest average rank indicates the lowest feed cost (most desirable); highest average rank indicates the highest feed cost (least desirable).

${ }^{6}$ Lowest average rank indicates the lowest IOFC (least desirable); highest average rank indicates the highest IOFC (most desirable). 
Table 11. Descriptive statistics for rank of feed costs with varying forage prices after 1,000 bootstrap replications of University of New Hampshire (UNH) economic data, with 1 indicating the lowest value and 4 indicating the highest value ${ }^{1}$

\begin{tabular}{|c|c|c|c|c|c|}
\hline $\begin{array}{l}\text { Price } \\
\text { change }^{2}(\%)\end{array}$ & Diet $^{3}$ & $\begin{array}{c}\text { Lowest } \\
\operatorname{rank}^{4}(\%)\end{array}$ & $\begin{array}{c}\text { Highest } \\
\operatorname{rank}^{5}(\%)\end{array}$ & $\begin{array}{l}\text { Average } \\
\text { rank }\end{array}$ & $\mathrm{SE}$ \\
\hline \multicolumn{6}{|l|}{-5} \\
\hline & $\mathrm{CSC}$ & 20.6 & 51.0 & 2.93 & 0.04 \\
\hline & CSP & 29.8 & 24.1 & 2.46 & 0.04 \\
\hline & GSC & 36.4 & 7.9 & 2.03 & 0.03 \\
\hline & GSP & 13.2 & 17.0 & 2.58 & 0.03 \\
\hline \multicolumn{6}{|l|}{-10} \\
\hline & CSP & $\begin{array}{l}20.8 \\
30.8\end{array}$ & $\begin{array}{l}50.5 \\
23.5\end{array}$ & $\begin{array}{l}2.92 \\
2.43\end{array}$ & $\begin{array}{l}0.04 \\
0.04\end{array}$ \\
\hline & GSC & 35.4 & 8.5 & 2.06 & 0.03 \\
\hline & GSP & 13.0 & 17.5 & 2.59 & 0.03 \\
\hline \multicolumn{6}{|l|}{-25} \\
\hline & $\mathrm{CSC}$ & 20.8 & 50.5 & 2.92 & 0.04 \\
\hline & CSP & 33.1 & 21.4 & 2.35 & 0.04 \\
\hline & GSC & 33.1 & 10.6 & 2.14 & 0.03 \\
\hline & GSP & 13.0 & 17.5 & 2.59 & 0.03 \\
\hline 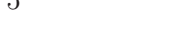 & $\mathrm{CSC}$ & 19.1 & 52.7 & 2.99 & 0.04 \\
\hline & CSP & 29.8 & 24.1 & 2.46 & 0.04 \\
\hline & GSC & 36.4 & 7.9 & 2.03 & 0.03 \\
\hline & GSP & 14.7 & \multicolumn{2}{|c|}{10} & 0.03 \\
\hline 10 & CSC & 18.9 & 52.8 & 3.00 & 0.04 \\
\hline & CSP & 30.8 & 24.1 & 2.45 & 0.04 \\
\hline & GSC & 35.4 & 7.9 & 2.04 & 0.03 \\
\hline \multirow{2}{*}{\multicolumn{6}{|c|}{25}} \\
\hline & & & & & \\
\hline & CSP & 28.3 & $\begin{array}{l}34.2 \\
24.1\end{array}$ & $\begin{array}{l}0.00 \\
2.48\end{array}$ & $\begin{array}{l}0.04 \\
0.04\end{array}$ \\
\hline & GSC & 39.9 & 5.4 & 1.91 & 0.03 \\
\hline & GSP & 13.9 & 16.3 & 2.56 & 0.03 \\
\hline
\end{tabular}

${ }^{1}$ Feed cost and income over feed costs (IOFC) data are averages over the 2 experimental periods.

${ }^{2}$ Percent that forage prices were decreased or increased, while holding grain prices constant.

${ }^{3} \mathrm{CSC}=$ corn silage-based diet supplemented with commodity concentrates; $\mathrm{CSP}=$ corn silage-based diet supplemented with a pelleted concentrate mixture; GSC = grass silage-based diet supplemented with commodity concentrates; GSP = grass silage-based diet supplemented with a pelleted concentrate mixture.

${ }^{4}$ Percent of 1,000 replications that each diet ranked lowest (rank of 1; most desirable).

${ }^{5}$ Percent of 1,000 replications that each diet ranked highest (rank of 4; least desirable).

the short duration of the experiment, it is possible that all cows were at or slightly past peak milk when the study concluded and that had the study lasted a few weeks longer all treatments would have had increased BCS.

\section{Feed Costs and IOFC}

Feed costs were significantly higher for CS diets $(P<$ 0.01 ) at UNH, but the interaction was not significant. In contrast, the costs of experimental diets at UMaine did not differ. Additionally, no differences were found among treatments for the value of the milk produced or the IOFC for cows at either location (Table 9). The average cost per cow per day of the diets ranged from $\$ 8.38$ (GSC) to $\$ 9.11$ (CSC) and from $\$ 7.57$ (GSC) to $\$ 8.11$ (CSC) for UNH and UMaine, respectively. Income over feed costs for UNH ranged from $\$ 6.38$ (CSC) to
$\$ 6.81$ (GSC) and from $\$ 11.12$ (CSC) to $\$ 11.71$ (GSC) for UMaine (Table 8). Differences between the 2 universities were a result of different levels of DMI and production between Holsteins and Jerseys. The average costs per cow per day were higher for UNH than for UMaine, which is the result of increases in feed prices between 2007 and 2008 .

Bailey et al. (1997) analyzed milk component data from the Mideast Federal Milk Marketing Order to simulate the economic returns of Pennsylvania Holstein and Jersey farms in a variety of situations. In all of the simulated scenarios, IOFC was found to be most influenced by the total amount of milk fat and milk protein produced. Godden et al. (2001) observed a positive relationship between MUN concentrations and feed costs, and a negative relationship between MUN and IOFC in Ontario dairy herds. Despite the higher MUN concentrations of GS fed cows, feed costs in the pres- 
Table 12. Descriptive statistics for rank of income over feed costs (IOFC) with varying forage prices after 1,000 bootstrap replications of University of New Hampshire (UNH) economic data, with 1 indicating the lowest value and 4 indicating the highest value ${ }^{1}$

\begin{tabular}{|c|c|c|c|c|c|}
\hline $\begin{array}{l}\text { Price } \\
\text { change }^{2}(\%)\end{array}$ & $\operatorname{Diet}^{3}$ & $\begin{array}{c}\text { Lowest } \\
\operatorname{rank}^{4}(\%)\end{array}$ & $\begin{array}{l}\text { Highest } \\
\operatorname{rank}^{5}(\%)\end{array}$ & $\begin{array}{l}\text { Average } \\
\text { rank }\end{array}$ & $\mathrm{SE}$ \\
\hline \multicolumn{6}{|l|}{-5} \\
\hline & $\mathrm{CSC}$ & 43.5 & 11.7 & 2.01 & 0.03 \\
\hline & CSP & 21.7 & 25.0 & 2.52 & 0.03 \\
\hline & GSC & 8.5 & 35.8 & 2.98 & 0.03 \\
\hline & GSP & 26.3 & 27.5 & 2.49 & 0.04 \\
\hline \multicolumn{6}{|l|}{-10} \\
\hline & CSC & 35.1 & 17.6 & 2.22 & 0.04 \\
\hline & CSP & 25.9 & 23.4 & 2.46 & 0.04 \\
\hline & GSC & 8.6 & 32.4 & 2.90 & 0.03 \\
\hline & GSP & 30.4 & 26.6 & 2.42 & 0.04 \\
\hline \multicolumn{6}{|l|}{-25} \\
\hline & CSC & 32.0 & 19.6 & 2.30 & 0.04 \\
\hline & CSP & 25.9 & 23.9 & 2.46 & 0.04 \\
\hline & GSC & 9.9 & 29.7 & 2.86 & 0.03 \\
\hline & GSP & 32.2 & 26.8 & 2.39 & 0.04 \\
\hline 5 & $\mathrm{CSC}$ & 36.0 & 17.6 & 2.21 & 0.04 \\
\hline & CSP & 25.7 & 23.7 & $\begin{array}{l}2.21 \\
2.46\end{array}$ & $\begin{array}{l}0.04 \\
0.04\end{array}$ \\
\hline & GSC & 9.7 & 31.4 & 2.88 & 0.03 \\
\hline & GSP & 28.6 & 27.3 & 2.45 & 0.04 \\
\hline 10 & $\mathrm{CSC}$ & 36.3 & 16.1 & 2.19 & 0.03 \\
\hline & CSP & 26.3 & 23.5 & 2.45 & 0.04 \\
\hline & GSC & 8.8 & 33.3 & 2.93 & 0.03 \\
\hline & GSP & 28.6 & 27.1 & 2.44 & 0.04 \\
\hline 25 & $\mathrm{CSC}$ & 33.5 & 14.4 & 2.21 & 0.03 \\
\hline & CSP & 25.4 & 23.2 & 2.44 & 0.03 \\
\hline & GSC & 9.9 & 33.2 & 2.90 & 0.03 \\
\hline & GSP & 31.2 & 29.2 & 2.45 & 0.04 \\
\hline
\end{tabular}

${ }^{1}$ IOFC data are averages over the 2 experimental periods.

${ }^{2}$ Percent that forage prices were decreased or increased, while holding grain prices constant.

${ }^{3} \mathrm{CSC}=$ corn silage-based diet supplemented with commodity concentrates; $\mathrm{CSP}=$ corn silage-based diet supplemented with a pelleted concentrate mixture; GSC = grass silage-based diet supplemented with commodity concentrates; GSP = grass silage-based diet supplemented with a pelleted concentrate mixture.

${ }^{4}$ Percent of 1,000 replications that each diet ranked lowest (rank of 1 ; least desirable).

${ }^{5}$ Percent of 1,000 replications that each diet ranked highest (rank of 4 ; most desirable).

ent study were numerically lower, whereas IOFC were numerically higher (Table 9).

The experimental diets of the current study were formulated to support similar levels of milk production for all treatment groups. No emphasis was placed on maximizing production, nor were nutritional strategies to alter milk component yields implemented. Because differences in milk yield and milk components were not observed, the dollar value of the milk produced was similar among treatments. Consequently, IOFC calculations in the current study were merely a reflection of the least-cost ration. However, based on the results of Bailey et al. (1997), increased profits could have been realized with greater milk fat or milk protein yield. Furthermore, without the constraints of feeding less than $40 \%$ concentrate, a better combination of dietary protein and fermentable carbohydrates may have been attained, which would likely have improved milk yield and milk component yields, while decreasing MUN concentrations. Feeding more supplemental carbohydrates may have increased ration costs in GS diets; however, the data of Godden et al. (2001) indicate that lowering MUN would actually further decrease costs, and, therefore, would increase profits.

Dhiman and Satter (1997) reported that a decrease in ruminal $\mathrm{NH}_{3}$ concentration improved efficiency of protein utilization and increased milk yield by decreasing dietary RDP as a result of replacing a portion of alfalfa silage with corn silage. Additionally, these researchers reported an economic incentive when corn silage comprised one-third of the dietary forage. Similarly, decreasing RDP supplementation resulted in improved $\mathrm{N}$ efficiency and greater net returns of simulated Wisconsin farms (Rotz et al., 1999). Furthermore, Rotz et al. (1999) observed decreased economic benefits when either alfalfa or corn silages were the sole forage in the 
Table 13. Descriptive statistics for rank of feed costs with varying grain prices after 1,000 bootstrap replications of University of New Hampshire (UNH) economic data, with 1 indicating the lowest value and 4 indicating the highest value ${ }^{1}$

\begin{tabular}{|c|c|c|c|c|c|}
\hline $\begin{array}{l}\text { Price } \\
\text { change }^{2}(\%)\end{array}$ & Diet $^{3}$ & $\begin{array}{l}\text { Lowest } \\
\operatorname{rank}^{4}(\%)\end{array}$ & $\begin{array}{l}\text { Highest } \\
\operatorname{rank}^{5}(\%)\end{array}$ & $\begin{array}{l}\text { Average } \\
\text { rank }\end{array}$ & $\mathrm{SE}$ \\
\hline \multicolumn{6}{|l|}{-5} \\
\hline & $\mathrm{CSC}$ & 18.9 & 52.9 & 3.00 & 0.04 \\
\hline & CSP & 29.8 & 24.1 & 2.46 & 0.04 \\
\hline & GSC & 36.4 & 7.9 & 2.03 & 0.03 \\
\hline & GSP & 14.9 & 15.1 & 2.51 & 0.03 \\
\hline \multicolumn{6}{|l|}{-10} \\
\hline & CSC & 18.6 & 53.6 & 3.02 & 0.04 \\
\hline & CSP & 29.8 & 24.1 & 2.46 & 0.04 \\
\hline & GSC & 37.0 & 6.5 & 1.99 & 0.03 \\
\hline & GSP & 14.6 & 15.8 & 2.53 & 0.03 \\
\hline \multicolumn{6}{|l|}{-25} \\
\hline & $\mathrm{CSC}$ & 15.9 & 55.7 & 3.12 & 0.04 \\
\hline & CSP & 28.3 & 24.1 & 2.48 & 0.04 \\
\hline & GSC & 41.7 & 4.2 & 1.85 & 0.03 \\
\hline & GSP & 14.1 & 16.0 & 2.56 & 0.03 \\
\hline \multicolumn{6}{|l|}{5} \\
\hline & CSP & 29.8 & $\begin{array}{l}01.4 \\
24.1\end{array}$ & $\begin{array}{l}2.44 \\
2.46\end{array}$ & 0.04 \\
\hline & GSC & 36.4 & 7.9 & 2.03 & 0.03 \\
\hline & GSP & 13.5 & 16.6 & 2.56 & 0.03 \\
\hline \multicolumn{6}{|l|}{10} \\
\hline & CSC & 17.2 & 50.5 & 2.96 & 0.04 \\
\hline & CSP & 27.7 & 24.2 & 2.49 & 0.04 \\
\hline & GSC & 42.1 & 7.0 & 1.95 & 0.03 \\
\hline & GSP & 13.0 & 18.3 & 2.60 & 0.03 \\
\hline 25 & $\mathrm{CSC}$ & 17.6 & 50.5 & 2.98 & 0.04 \\
\hline & CSP & 25.8 & 22.6 & 2.46 & 0.03 \\
\hline & GSC & 45.9 & 6.4 & 1.88 & 0.03 \\
\hline & GSP & 10.7 & 20.5 & 2.68 & 0.03 \\
\hline
\end{tabular}

${ }^{1}$ Feed cost data are averages over the 2 experimental periods.

${ }^{2}$ Percent that grain prices were increased or decreased, while holding forage prices constant.

${ }^{3} \mathrm{CSC}=$ corn silage-based diet supplemented with commodity concentrates; $\mathrm{CSP}=$ corn silage-based diet supplemented with a pelleted concentrate mixture; GSC = grass silage-based diet supplemented with commodity concentrates; GSP = grass silage-based diet supplemented with a pelleted concentrate mixture.

${ }^{4}$ Percent of 1,000 replications that each diet ranked lowest (rank of 1; most desirable).

${ }^{5}$ Percent of 1,000 replications that each diet ranked highest (rank of 4; least desirable).

ration, or when alfalfa comprised a significant portion of the forage component of the ration. Grass silage diets fed at UNH and UMaine were a mixture of grasses and legumes and were not comprised of alfalfa silage alone; therefore, $\mathrm{N}$ efficiency may have been greater in the current study than in those of Dhiman and Satter (1997) and (Rotz et al., 1999).

Results of the bootstrap analysis are shown in Table 10. Following the 1,000 bootstrap replications, the CSC diet had the highest feed cost (ranking fourth) 51.1 and $54.1 \%$ of the time for UNH and UMaine, respectively. In addition, bootstrap replications indicated that GSC was generally the least-cost ration, being ranked 1 in $36.4 \%$ of UNH replications and $59.8 \%$ of UMaine replications. In contrast, following the 1,000 IOFC replications, GSC was ranked fourth (highest IOFC) in $40.2 \%$ of UNH replications and $38.4 \%$ of UMaine replications, indicating that GSC was the most profitable of the 4 experimental diets. Additionally, CSC had the lowest IOFC (rank of 1) in $37.4 \%$ of UNH replications and $40.1 \%$ of UMaine replications.

The results of the sensitivity analyses for UNH feed cost replications with varying forage prices are presented in Table 11. Feed cost sensitivity analyses demonstrated that CSC had the highest feed cost in all 3 forage price increase or decrease levels (Table 11). Decreasing the price of each forage in the ration by $5 \%$ resulted in CSC being ranked fourth in $51 \%$ of the 1,000 bootstrap replications and $50.5 \%$ of the replications when the forage prices were decreased by both 10 and $25 \%$. Corn silage with commodities also was ranked fourth in 52.7, 52.8, and $54.2 \%$ of replications when the forage prices were increased by 5,10 , or $25 \%$, respectively. Decreasing the forage prices resulted in GSC having the lowest rank in $36.4 \%$ of the replications at a $5 \%$ decrease, and $35.4 \%$ of replications at 
Table 14. Descriptive statistics for rank of income over feed costs (IOFC) with varying grain prices after 1,000 bootstrap replications of University of New Hampshire (UNH) economic data, with 1 indicating the lowest value and 4 indicating the highest value ${ }^{1}$

\begin{tabular}{|c|c|c|c|c|c|}
\hline $\begin{array}{l}\text { Price } \\
\text { change }^{2}(\%)\end{array}$ & Diet $^{3}$ & $\begin{array}{c}\text { Lowest } \\
\operatorname{rank}^{4}(\%)\end{array}$ & $\begin{array}{l}\text { Highest } \\
\operatorname{rank}^{5}(\%)\end{array}$ & $\begin{array}{l}\text { Average } \\
\text { rank }\end{array}$ & $\mathrm{SE}$ \\
\hline \multicolumn{6}{|l|}{-5} \\
\hline & $\mathrm{CSC}$ & 36.1 & 15.5 & 2.19 & 0.03 \\
\hline & CSP & 26.1 & 19.9 & 2.40 & 0.03 \\
\hline & GSC & 7.8 & 39.7 & 3.02 & 0.03 \\
\hline \multirow{2}{*}{\multicolumn{6}{|c|}{-10}} \\
\hline & & & & & \\
\hline & CSC & 38.7 & 15.8 & 2.15 & 0.03 \\
\hline & CSP & 24.4 & 23.4 & 2.47 & 0.03 \\
\hline & GSC & 8.1 & 33.4 & 2.93 & 0.03 \\
\hline \multirow{2}{*}{\multicolumn{6}{|c|}{-25}} \\
\hline & & & & & \\
\hline & $\mathrm{CSC}$ & 39.3 & 12.8 & 2.09 & 0.03 \\
\hline & CSP & 25.1 & 24.0 & 2.47 & 0.04 \\
\hline & GSC & 7.8 & 35.5 & 2.96 & 0.03 \\
\hline \multirow{2}{*}{\multicolumn{6}{|c|}{ UNA }} \\
\hline & & & & & \\
\hline & CSC & 38.1 & 10.9 & 2.07 & 0.03 \\
\hline & CSP & 25.1 & 25.6 & 2.51 & 0.04 \\
\hline & GSC & 8.3 & 35.8 & 2.96 & 0.03 \\
\hline & GSP & 28.5 & 27.7 & 2.46 & 0.04 \\
\hline \multicolumn{6}{|l|}{10} \\
\hline & $\mathrm{CSC}$ & 40.3 & 12.2 & 2.06 & 0.03 \\
\hline & CSP & 23.4 & 25.5 & 2.52 & 0.04 \\
\hline & GSC & 8.6 & 34.0 & 2.95 & 0.03 \\
\hline & GSP & 27.7 & 28.3 & 2.47 & 0.04 \\
\hline 25 & CSC & 42.2 & 12.3 & 2.04 & 0.03 \\
\hline & CSP & 23.2 & 23.5 & 2.49 & 0.03 \\
\hline & GSC & 7.9 & 38.6 & 3.02 & 0.03 \\
\hline & GSP & 26.7 & 25.6 & 2.45 & 0.04 \\
\hline
\end{tabular}

${ }^{1}$ IOFC data are averages over the 2 experimental periods.

${ }^{2}$ Percent that grain prices were increased or decreased, while holding forage prices constant.

${ }^{3} \mathrm{CSC}=$ corn silage-based diet supplemented with commodity concentrates; $\mathrm{CSP}=$ corn silage-based diet supplemented with a pelleted concentrate mixture; GSC = grass silage-based diet supplemented with commodity concentrates; GSP = grass silage-based diet supplemented with a pelleted concentrate mixture.

${ }^{4}$ Percent of 1,000 replications that each diet ranked lowest (rank of 1 ; least desirable).

${ }^{5}$ Percent of 1,000 replications that each diet ranked highest (rank of 4 ; most desirable).

a $10 \%$ forage price decrease. However, decreasing the price of the forages by $25 \%$ resulted in GSC and CSP being tied for the lowest rank in $33.1 \%$ of the 1,000 replications each. Grass silage with commodities alone most often had the lowest rank when forage prices were increased. Increasing the price of the forages by 5,10 , and $25 \%$ resulted in GSC having the lowest rank 36.4, 35.4 , and $39.9 \%$ of the time, respectively (Table 11 ).

The 1,000 bootstrap replications indicated that GSC was most often ranked the highest when grain prices changed. Grass silage with commodities had the highest rank in $35.8,32.4$, and $29.7 \%$ of the replications for the 5,10 , and $25 \%$ price decreases, and 31.4, 33.3, and $33.2 \%$ of replications for the 5,10 , and $25 \%$ price increases, respectively. In addition, for the 5, 10, and $25 \%$ forage price decreases, CSC was ranked lowest, or was the least profitable in $43.5,35.1$, and $32.0 \%$ of replications, respectively (Table 12).
Increasing and decreasing the price of the grains by the same margin, while holding forage prices constant, also resulted in CSC being ranked highest and GSC being ranked lowest in the majority of the bootstrap replications (Table 13). When grain prices were decreased by $5 \%$, CSC had the highest rank in $52.9 \%$ of feed cost replications, whereas GSC had the lowest rank in $36.4 \%$ of replications. Similar results were observed by decreasing the grain prices by 10 and $25 \%$, as CSC feed costs were ranked highest in 53.6 and $55.7 \%$ of replications, whereas GSC was ranked lowest in 37.0 and $41.7 \%$ of replications, respectively (Table 13 ).

Income over feed cost results for changes in grain prices showed similar patterns to those observed for the forage prices and are shown in Table 14. Decreasing the price of the grains included in the rations by $5 \%$ resulted in GSC having the highest rank in $39.7 \%$ of replications, whereas CSC had the lowest rank in 
Table 15. Descriptive statistics for rank of feed costs with varying forage prices after 1,000 bootstrap replications of University of Maine (UMaine) economic data, with 1 indicating the lowest value and 4 indicating the highest value ${ }^{1}$

\begin{tabular}{|c|c|c|c|c|c|}
\hline $\begin{array}{l}\text { Price } \\
\text { change }^{2}(\%)\end{array}$ & Diet $^{3}$ & $\begin{array}{c}\text { Lowest } \\
\operatorname{rank}^{4}(\%)\end{array}$ & $\begin{array}{l}\text { Highest } \\
\operatorname{rank}^{5}(\%)\end{array}$ & $\begin{array}{l}\text { Average } \\
\text { rank }\end{array}$ & $\mathrm{SE}$ \\
\hline \multicolumn{6}{|l|}{-5} \\
\hline & $\mathrm{CSC}$ & 6.7 & 52.3 & 3.18 & 0.03 \\
\hline & CSP & 32.4 & 31.2 & 2.58 & 0.04 \\
\hline & GSC & 48.2 & 4.5 & 1.77 & 0.03 \\
\hline & GSP & 12.7 & 12.0 & 2.47 & 0.03 \\
\hline \multicolumn{6}{|l|}{-10} \\
\hline & CSC & 5.6 & 54.1 & 3.23 & 0.03 \\
\hline & CSP & 54.9 & 24.5 & 2.15 & 0.04 \\
\hline & GSC & 30.1 & 6.5 & 2.02 & 0.03 \\
\hline & GSP & 9.4 & 14.9 & 2.60 & 0.03 \\
\hline \multicolumn{6}{|l|}{-25} \\
\hline & CSC & 5.6 & 54.1 & 3.23 & 0.03 \\
\hline & CSP & 54.9 & 24.5 & 2.15 & 0.04 \\
\hline & GSC & 30.1 & 6.5 & 2.02 & 0.03 \\
\hline & GSP & 9.4 & 14.9 & 2.60 & 0.03 \\
\hline \multicolumn{6}{|l|}{5} \\
\hline & CSC & 5.6 & 54.1 & 3.23 & 0.03 \\
\hline & CSP & 34.2 & 24.5 & 2.35 & 0.04 \\
\hline & GSC & 50.8 & 6.5 & 1.81 & 0.03 \\
\hline & GSP & 9.4 & 14.9 & 2.60 & 0.03 \\
\hline \multicolumn{6}{|l|}{10} \\
\hline & CSC & 6.6 & 53.3 & 3.20 & 0.03 \\
\hline & CSP & 18.3 & 25.3 & 2.60 & 0.03 \\
\hline & GSC & 59.8 & 6.5 & 1.72 & 0.03 \\
\hline & GSP & 15.3 & 14.9 & 2.48 & 0.03 \\
\hline & $\mathrm{CSC}$ & 9.3 & \multicolumn{2}{|c|}{25} & 0.03 \\
\hline & CSP & 29.4 & 24.5 & 2.40 & 0.04 \\
\hline & GSC & 55.6 & 6.5 & 1.77 & 0.03 \\
\hline & GSP & 5.7 & 19.9 & 2.77 & 0.03 \\
\hline
\end{tabular}

${ }^{1}$ Feed cost data are averages over the 2 experimental periods.

${ }^{2}$ Percent that grain prices were increased or decreased, while holding forage prices constant.

${ }^{3} \mathrm{CSC}=$ corn silage-based diet supplemented with commodity concentrates; $\mathrm{CSP}=$ corn silage-based diet supplemented with a pelleted concentrate mixture; GSC = grass silage-based diet supplemented with commodity concentrates; GSP = grass silage-based diet supplemented with a pelleted concentrate mixture.

${ }^{4}$ Percent of 1,000 replications that each diet ranked lowest (rank of 1 ; most desirable).

${ }^{5}$ Percent of 1,000 replications that each diet ranked highest (rank of 4 ; least desirable).

$36.1 \%$ of replications. At a $10 \%$ price decrease, GSC was ranked highest in $33.4 \%$ of replications and CSC was ranked lowest in $38.7 \%$ of replications. Additionally, GSC was ranked highest in $35.5 \%$ of replications, whereas CSC was ranked lowest in $39.3 \%$ of replications at a $25 \%$ decrease in the price of grain. Increasing the prices of the grains by 5,10 , and $25 \%$ resulted in GSC having the highest rank in $35.8,34.0$, and $38.6 \%$ of replications, respectively. Furthermore, increasing the grain prices by 5,10 , and $25 \%$ resulted in CSC having the lowest rank in $38.1,40.3$, and $42.2 \%$ of replications, respectively. Of interest, CSP and GSP were most often ranked in the middle for feed costs and IOFC at all levels of feed price changes; however, no clear patterns were observed (Table 14).

Similar to UNH, UMaine replications indicated that decreasing the price of the forages by 5,10 , and $25 \%$ would result in CSC having the greatest feed cost in
$52.3,54.1$, and $54.1 \%$ of the replications, respectively, whereas increasing the price by the same margins would result in CSC having the highest feed cost in $54.1,53.3$, and $49.1 \%$ of replications, respectively (Table 15). Increasing the prices of the forages by 5 , 10 , and $25 \%$ resulted in GSC having the lowest feed cost in $50.8,59.8$, and $55.6 \%$ of the replications, respectively and decreasing the price by $5 \%$ also resulted in GSC having the lowest feed cost $48.2 \%$ of the time. However, decreasing the forage prices by 10 and $25 \%$ resulted in CSP having the lowest feed cost more often than did GSC. At both a 10 and 25\% decrease in the price of the forage, CSP had the lowest rank in $54.9 \%$ of the replications, compared with GSC only being ranked the lowest in $30.1 \%$ of replications at both price decrease levels, indicating that at extremely low forage prices, feeding CSP may be beneficial to decrease input costs. 
Table 16. Descriptive statistics for rank of income over feed costs (IOFC) with varying forage prices after 1,000 bootstrap replications of University of Maine (UMaine) economic data, with 1 indicating the lowest value and 4 indicating the highest value ${ }^{1}$

\begin{tabular}{|c|c|c|c|c|c|}
\hline $\begin{array}{l}\text { Price } \\
\text { change }^{2}(\%)\end{array}$ & Diet $^{3}$ & $\begin{array}{l}\text { Lowest } \\
\operatorname{rank}^{4}(\%)\end{array}$ & $\begin{array}{l}\text { Highest } \\
\operatorname{rank}^{4}(\%)\end{array}$ & $\begin{array}{l}\text { Average } \\
\text { rank }\end{array}$ & $\mathrm{SE}$ \\
\hline \multicolumn{6}{|l|}{-5} \\
\hline & $\mathrm{CSC}$ & 35.8 & 22.7 & 2.27 & 0.03 \\
\hline & CSP & 25.4 & 22.4 & 2.45 & 0.03 \\
\hline & GSC & 13.1 & 29.7 & 2.78 & 0.03 \\
\hline & GSP & 25.7 & 25.2 & 2.50 & 0.04 \\
\hline \multicolumn{6}{|l|}{-10} \\
\hline & CSC & 37.0 & 23.4 & 2.29 & 0.03 \\
\hline & CSP & 22.8 & 25.5 & 2.53 & 0.03 \\
\hline & GSC & 14.3 & 25.6 & 2.69 & 0.03 \\
\hline & GSP & 25.9 & 25.5 & 2.49 & 0.04 \\
\hline-25 & $\mathrm{CSC}$ & 36.7 & 23.4 & 2.29 & 0.03 \\
\hline & CSP & 23.1 & 24.9 & 2.52 & 0.04 \\
\hline & GSC & 14.1 & 26.0 & 2.70 & 0.03 \\
\hline & GSP & 26.1 & 25.7 & 2.49 & 0.04 \\
\hline \multicolumn{6}{|l|}{5} \\
\hline & $\mathrm{CSC}$ & 37.1 & 21.5 & 2.26 & 0.03 \\
\hline & CSP & 23.5 & 22.0 & 2.48 & 0.04 \\
\hline & GSC & 13.1 & 32.2 & 2.80 & 0.03 \\
\hline & GSP & 26.3 & 24.3 & 2.47 & 0.04 \\
\hline \multicolumn{2}{|l|}{10} & 37.0 & 22.4 & & 0.03 \\
\hline & CSP & 24.5 & 22.2 & 2.46 & 0.04 \\
\hline & GSC & 12.2 & 32.0 & 2.81 & 0.03 \\
\hline & GSP & 26.3 & 23.4 & 2.46 & 0.04 \\
\hline \multicolumn{5}{|l|}{25} & 0.03 \\
\hline & CSP & 24.4 & 21.8 & 2.46 & 0.03 \\
\hline & GSC & 11.7 & 32.9 & 2.83 & 0.03 \\
\hline & GSP & 26.5 & 23.1 & 2.45 & 0.04 \\
\hline
\end{tabular}

${ }^{1}$ IOFC data are averages over the 2 experimental periods.

${ }^{2}$ Percent that forage prices were increased or decreased, while holding grain prices constant.

${ }^{3} \mathrm{CSC}=$ corn silage-based diet supplemented with commodity concentrates; $\mathrm{CSP}=$ corn silage-based diet supplemented with a pelleted concentrate mixture; GSC = grass silage-based diet supplemented with commodity concentrates; GSP = grass silage-based diet supplemented with a pelleted concentrate mixture.

${ }^{4}$ Percent of 1,000 replications that each diet ranked lowest (rank of 1 ; least desirable).

${ }^{5}$ Percent of 1,000 replications that each diet ranked highest (rank of 4; most desirable).

Grass silage with commodities had the highest IOFC when the forage prices were decreased by 5,10 , and $25 \%$, ranking highest in $29.7,25.6$, and $26.0 \%$ of replications. However, CSP ranked the highest in $25.5 \%$ of replications at a $10 \%$ decrease, and $24.9 \%$ of replications at a $25 \%$ decrease, indicating that at lower forage prices, CSP may have an economic benefit to producers. However, when the price was increased by 5,10 , and $25 \%$, GSC had the highest IOFC, ranking fourth in $32.2,32.0$, and $32.9 \%$ of replications, respectively. Similar to UNH, at all levels of forage price increase or decrease, CSC most often had the lowest IOFC, ranking lowest $35.8,37.0$, and $36.7 \%$ of the time for a 5,10 , or $25 \%$ decrease, respectively, and $37.1,37.0$, and $37.4 \%$ of the time for a 5,10 , or $25 \%$ forage price increase, respectively (Table 16).

Decreasing the price of grain by $5 \%$ resulted in CSC having the highest rank in $54.1 \%$ of replications, where- as GSC had the lowest rank in $50.8 \%$ of replications. Corn silage with commodities also had the highest rank $53.5 \%$ of the time when the grain prices were decreased by $10 \%$ and ranked highest $46.6 \%$ of the time when the grain price was decreased by $25 \%$. Grass silage with commodities, on the other hand, ranked lowest in 54.9 and $59.8 \%$ of the replications at the 10 and $25 \%$ grain price decreases, respectively. Similar results were obtained when the grain prices were increased, as CSC had the highest rank in 55.4, 54.1, and $52.4 \%$ of the replications, whereas GSC had the lowest rank in 54.1, 59.8 , and $63.0 \%$ of the replications at the 5,10 , and $25 \%$ price decrease levels, respectively (Table 17).

Income over feed costs for the grain price decreases favored GSC, which had the highest rank in $36.2 \%$ of the replications at a $5 \%$ price decrease, $35.3 \%$ of the replications at a $10 \%$ decrease, and $35.0 \%$ of the replications at a $25 \%$ decrease in grain price. Grass silage 
Table 17. Descriptive statistics for rank of feed costs with varying grain prices after 1,000 bootstrap replications of University of Maine (UMaine) economic data, with 1 indicating the lowest value and 4 indicating the highest value $^{1}$

\begin{tabular}{|c|c|c|c|c|c|}
\hline $\begin{array}{l}\text { Price } \\
\text { change }^{2}(\%)\end{array}$ & $\operatorname{Diet}^{3}$ & $\begin{array}{l}\text { Lowest } \\
\operatorname{rank}^{4}(\%)\end{array}$ & $\begin{array}{l}\text { Highest } \\
\operatorname{rank}^{5}(\%)\end{array}$ & $\begin{array}{l}\text { Average } \\
\text { rank }\end{array}$ & $\mathrm{SE}$ \\
\hline \multicolumn{6}{|l|}{-5} \\
\hline & $\mathrm{CSC}$ & 5.6 & 54.1 & 3.23 & 0.03 \\
\hline & CSP & 34.2 & 24.5 & 2.35 & 0.04 \\
\hline & GSC & 50.8 & 6.5 & 1.81 & 0.03 \\
\hline & GSP & 9.4 & 14.9 & 2.60 & 0.03 \\
\hline \multicolumn{6}{|l|}{-10} \\
\hline & $\mathrm{CSC}$ & 6.0 & 53.5 & 3.22 & 0.03 \\
\hline & CSP & 30.1 & 24.5 & 2.15 & 0.04 \\
\hline & GSC & 54.9 & 6.5 & 2.02 & 0.03 \\
\hline \multirow{2}{*}{\multicolumn{6}{|c|}{-25}} \\
\hline & & & & & \\
\hline & $\mathrm{CSC}$ & 10.7 & 46.6 & 2.12 & 0.03 \\
\hline & CSP & 25.2 & 24.5 & 2.47 & 0.04 \\
\hline & GSC & 59.8 & 6.5 & 2.83 & 0.03 \\
\hline & GSP & 4.3 & 22.4 & 2.58 & 0.03 \\
\hline & \multicolumn{5}{|c|}{5} \\
\hline & CSP & 34.3 & 24.5 & $\begin{array}{l}0.20 \\
2.35\end{array}$ & 0.04 \\
\hline & GSC & 54.1 & 5.2 & 1.71 & 0.03 \\
\hline & GSP & 6.9 & 14.9 & 2.65 & 0.03 \\
\hline \multicolumn{6}{|l|}{10} \\
\hline & $\begin{array}{l}\text { CSC } \\
\text { CSP }\end{array}$ & 5.6 & 54.1 & $\begin{array}{l}3.23 \\
264\end{array}$ & 0.03 \\
\hline & GSC & $\begin{array}{l}16.7 \\
59.8\end{array}$ & $\begin{array}{r}24.5 \\
6.5\end{array}$ & $\begin{array}{l}2.64 \\
1.72\end{array}$ & $\begin{array}{l}0.03 \\
0.03\end{array}$ \\
\hline & GSP & 17.9 & 14.9 & 2.41 & 0.03 \\
\hline \multicolumn{6}{|l|}{25} \\
\hline & $\mathrm{CSC}$ & 4.6 & 52.4 & 3.21 & 0.03 \\
\hline & CSP & 23.5 & 33.4 & 2.74 & 0.04 \\
\hline & GSC & 63.0 & 2.2 & 1.52 & 0.02 \\
\hline & GSP & 9.3 & 11.6 & 2.52 & 0.03 \\
\hline
\end{tabular}

${ }^{1}$ Feed cost data are averages over the 2 experimental periods.

${ }^{2}$ Percent that grain prices were increased or decreased, while holding forage prices constant.

${ }^{3} \mathrm{CSC}=$ corn silage-based diet supplemented with commodity concentrates; $\mathrm{CSP}=$ corn silage-based diet supplemented with a pelleted concentrate mixture; GSC = grass silage-based diet supplemented with commodity concentrates; GSP = grass silage-based diet supplemented with a pelleted concentrate mixture.

${ }^{4}$ Percent of 1,000 replications that each diet ranked lowest (rank of 1; most desirable).

${ }^{5}$ Percent of 1,000 replications that each diet ranked highest (rank of 4; least desirable).

with commodities was also ranked highest in $37.1,36.6$, and $34.5 \%$ of the replications at a 5,10 , and $25 \%$ grain price increase, respectively. Corn silage with commodities had the lowest IOFC rank most of the time for all levels of grain price changes, ranking lowest 36.7 and $38.5 \%$ of the time for the $5 \%$ decrease and a $5 \%$ increase in grain price, respectively. Decreasing the grain price by $10 \%$ resulted in CSC having the lowest ranking $37.0 \%$ of the time, whereas $38.2 \%$ of the time it had the lowest rank for a $10 \%$ price increase, and in 37.1 and $38.5 \%$ of the replications it had the lowest rank for a $25 \%$ price decrease or price increase, respectively (Table 18).

A significant portion of the daily input costs on an organic dairy are allocated toward the production and purchase of feedstuffs (Dalton et al., 2008). Therefore, choosing complementary forages and concentrates that will support an adequate level of milk production, without supplying unnecessary, excess nutrients is critical to improve profitability. Bootstrap replications from both universities indicated that feeding organic dairy cows in New England a grass silage-based diet supplemented with commodities will, generally, result in the lowest feed costs. In addition, because GSC was able to support the same level of milk production and similar components, BW, and BCS to the other TMR evaluated, this diet was most often associated with the highest IOFC. Sensitivity analyses also demonstrated that when both forage and grain prices increase, grass silage-based diets supplemented with commodities will likely still be the lowest-cost ration and yield the greatest profitability. However, the sensitivity analyses showed that when forage prices are decreased by 10 or $25 \%$, feeding a corn silage-based diet supplemented with a pelleted grain may also be a viable option to decrease feed costs. Conversely, at similar milk and 
Table 18. Descriptive statistics for rank of income over feed costs (IOFC) with varying grain prices after 1,000 bootstrap replications of University of Maine (UMaine) economic data, with 1 indicating the lowest value and 4 indicating the highest value ${ }^{1}$

\begin{tabular}{|c|c|c|c|c|c|}
\hline $\begin{array}{l}\text { Price } \\
\text { change }^{2}(\%)\end{array}$ & Diet $^{3}$ & $\begin{array}{c}\text { Lowest } \\
\operatorname{rank}^{4}(\%)\end{array}$ & $\begin{array}{l}\text { Highest } \\
\operatorname{rank}^{5}(\%)\end{array}$ & $\begin{array}{l}\text { Average } \\
\text { rank }\end{array}$ & $\mathrm{SE}$ \\
\hline \multicolumn{6}{|l|}{-5} \\
\hline & $\mathrm{CSC}$ & 36.7 & 20.9 & 2.25 & 0.04 \\
\hline & CSP & 24.1 & 20.2 & 2.44 & 0.03 \\
\hline & GSC & 12.6 & 36.2 & 2.87 & 0.03 \\
\hline & GSP & 26.6 & 22.7 & 2.44 & 0.04 \\
\hline \multicolumn{6}{|l|}{-10} \\
\hline & CSC & 37.0 & 20.9 & 2.24 & 0.04 \\
\hline & CSP & 23.7 & 21.6 & 2.47 & 0.03 \\
\hline & GSC & 12.5 & 35.3 & 2.86 & 0.03 \\
\hline & GSP & 26.8 & 22.2 & 2.43 & 0.04 \\
\hline \multicolumn{6}{|l|}{-25} \\
\hline & CSC & 37.1 & 21.3 & 2.25 & 0.04 \\
\hline & CSP & 24.3 & 20.9 & 2.43 & 0.03 \\
\hline & GSC & 10.3 & 35.0 & 2.90 & 0.03 \\
\hline & GSP & 28.3 & 22.8 & 2.42 & 0.04 \\
\hline \multicolumn{6}{|l|}{5} \\
\hline & CSC & 38.5 & 20.8 & 2.22 & 0.04 \\
\hline & CSP & 24.6 & 20.2 & 2.42 & 0.03 \\
\hline & GSC & 9.7 & 37.1 & 2.94 & 0.03 \\
\hline & GSP & 27.2 & 21.9 & 2.41 & 0.04 \\
\hline 10 & $\mathrm{CSC}$ & 38.2 & 20.6 & 2.23 & 0.04 \\
\hline & CSP & 25.0 & 20.1 & 2.41 & 0.03 \\
\hline & GSC & 9.6 & 36.6 & 2.94 & 0.03 \\
\hline & GSP & 27.2 & 22.7 & 2.42 & 0.04 \\
\hline 20 & $\mathrm{CSC}$ & 38.5 & 20.9 & 2.23 & 0.04 \\
\hline & CSP & 22.9 & 23.0 & 2.49 & 0.03 \\
\hline & GSC & 12.1 & 34.5 & 2.86 & 0.03 \\
\hline & GSP & 26.5 & 21.6 & 2.42 & 0.03 \\
\hline
\end{tabular}

${ }^{1}$ IOFC data are averages over the 2 experimental periods.

${ }^{2}$ Percent that grain prices were increased or decreased, while holding forage prices constant.

${ }^{3} \mathrm{CSC}=$ corn silage-based diet supplemented with commodity concentrates; $\mathrm{CSP}=$ corn silage-based diet supplemented with a pelleted concentrate mixture; GSC = grass silage-based diet supplemented with commodity concentrates; GSP = grass silage-based diet supplemented with a pelleted concentrate mixture.

${ }^{4}$ Percent of 1,000 replications that each diet ranked lowest (rank of 1 ; least desirable).

${ }^{5}$ Percent of 1,000 replications that each diet ranked highest (rank of 4 ; most desirable).

component yields as were observed in the current study, the decrease in feed costs may not necessarily increase profitability, as IOFC still favored the GSC diets even when CSP had similar (UNH) or lower (UMaine) feed costs. An important point to consider, however, is that although IOFC is indicative of profitability, it does not represent the overall success of a dairy farm enterprise. Thus, the overall cost of production and whole-farm budget analyses, nutrient flows, and producer preferences should all be considered before any feeding changes are made.

\section{CONCLUSIONS}

The diets used in this experiment were formulated to simulate rations that are currently fed to dairy cows in New England that are managed according to the USDA-certified organic system. Diets were formulated to contain $60 \%$ or greater forage, with little empha- sis placed on maximizing production. Based on these constraints, experimental diets and the resulting milk yield and composition were similar throughout this study. However, results of the 1,000 bootstrap replications indicated that cows fed grass silage-based diets supplemented with commodity concentrates had lower feed costs and higher IOFC compared with cows fed grass silage-based diets supplemented with a pelleted concentrate supplement or corn silage-based diets with either type of supplementation. Additionally, a pattern for corn silage-based diets supplemented with commodity concentrates to have the highest feed costs was observed in this study. Although many factors contribute to the profitability of a dairy farm, results from the current study indicate that grass silage-based diets supplemented with commodity concentrates can potentially provide an economic advantage for New England dairy producers using an organic system of production. 


\section{ACKNOWLEDGMENTS}

The authors acknowledge the Cooperative State Research, Education, and Extension Service, USDA Integrated Organic Program under Agreement No. 2005-51106-02392 for the financial support of this study. We also appreciate the support and cooperation of the personnel at the Organic Dairy Research Farm at the University of New Hampshire, the J. R. Witter Center at the University of Maine and USDA/ARS New England Plant Soil and Water Laboratory at the University of Maine. In addition, we thank the Maine Organic Milk Producers Association for their input and support throughout this project.

\section{REFERENCES}

AOAC International. 2002. 17th ed. Rev. 1. Official Methods of Analysis. Gaithersburg, MD.

Bailey, K., D. Hardin, J. Spain, J. Garrett, J. Hoehne, R. Randle, R. Ricketts, B. Steevens, and J. Zulovich. 1997. An economic simulation study of large-scale dairy units in the Midwest. J. Dairy Sci. 80:205-214.

Boos, D. D. 2003. Introduction to the bootstrap world. Stat. Sci. 18:168-174.

Broderick, G. A. 1995. Desirable characteristics of forage legumes for improving protein utilization in ruminants. J. Anim. Sci. $73: 2760-2773$.

Chernick, M. R. 1999. Bootstrap Methods: A Practioner's Guide. John Wiley \& Sons, Inc. New York, NY.

Dalton, T. J., R. Parsons, R. Kersbergen, G. Rogers, D. Kauppila, L. McCrory, L. A. Bragg, and Q. Wang. 2008. A comparative analysis of organic dairy farms in Maine and Vermont: Farm financial information from 2004 to 2006. Maine Agric. and Forest Exper. Stat. Bull. No. 851. University of Maine, Orono, ME.

Dhiman, T. R., and L. D. Satter. 1997. Yield response of dairy cows fed different proportions of alfalfa silage and corn silage. J. Dairy Sci. 80:2069-2082.
Efron, B. 1982. The Jackknife, the Bootstrap and other Resampling Plans. Soc. Industrial Appl. Math., Philadelphia, PA.

Gloy, B. A., L. W. Tauer, and W. Knoblauch. 2002. Profitability of grazing versus mechanical forage harvesting on New York dairy farms. J. Dairy Sci. 85:2215-2222.

Godden, S. M., K. D. Lissemore, D. F. Kelton, K. E. Leslie, J. S. Walton, and J. H. Lumsden. 2001. Factors associated with milk urea concentrations in Ontario dairy herds. J. Dairy Sci. 84:107-114.

Janovick-Guretzky, N. A., H. M. Dann, D. B. Carlson, M. R. Murphy, J. J. Loor, and J. K. Drackley. 2007. Housekeeping gene expression in bovine liver is affected by physiological state, feed intake, and dietary treatment. J. Dairy Sci. 90:2246-2252.

Johnson, L., J. H. Harrison, C. Hunt, K. Shinners, C. G. Doggett, and D. Sapienza. 1999. Nutritive value of corn silage as affected by maturity and mechanical processing: A contemporary review. J. Dairy Sci. 82:2813-2825.

Jonker, J. S., R. A. Kohn, and R. A. Erdman. 1998. Using milk urea nitrogen to predict nitrogen excretion and utilization efficiency in lactating dairy cows. J. Dairy Sci. 81:2681-2692.

Kononoff, P. J., A. J. Heinrichs, and D. R. Buckmaster. 2003. Modification of the Penn State forage and total mixed ration particle and the effects of moisture content on its measurements. J. Dairy Sci. 86:1858-1863.

Manly, B. F. J. 1997. Randomization, Bootstrap and Monte Carlo Methods in Biology. 2nd ed. CRC Press, Boca Raton, FL.

McBride, W. D., and C. Greene. 2009. Characteristics, costs, and issues for organic dairy farming. Econ. Res. Rep. No. 82. USDAERS, Washington, DC.

NRC. 2001. Nutrient Requirements of Dairy Cattle. 7th rev. ed. Natl. Acad. Sci., Washington, DC.

Oba, M., and M. S. Allen. 1999. Evaluation of the importance of the digestibility of neutral detergent fiber from forage: Effects on dry matter intake and milk yield of dairy cows. J. Dairy Sci. 82:589-596.

Rotz, C. A., L. D. Satter, D. R. Mertens, and R. E. Muck. 1999. Feeding strategy, nitrogen cycling, and profitability of dairy farms. J. Dairy Sci. 82:2841-2855.

SAS Institute. 2004. SAS/STAT User's Guide. Version 9.2. SAS Institute, Inc., Cary, NC.

VandeHaar, M. J., and N. St-Pierre. 2006. Major advances in nutrition: Relevance to the sustainability of the dairy industry. J. Dairy Sci. 89:1280-1291. 